\title{
Ectoparasites of murids in peninsular Malaysia and their associated diseases
}

\author{
Siti Nursheena Mohd Zain ${ }^{1 *}$, Syed Arnez Syed Khalil Amdan², Kamil A Braima ${ }^{3}$, Noraishah M Abdul-Aziz ${ }^{3}$, \\ John-James Wilson ${ }^{1,4}$, Paramesvaran Sithambaran ${ }^{5}$ and John Jeffery ${ }^{3}$
}

\begin{abstract}
A considerable number of rat-borne ectoparasite studies have been conducted since the early 1930s in the Malayan Peninsula (now known as peninsular Malaysia). The majority of studies were field surveys and collections of specimens across the region, and were conducted primarily to catalogue the ectoparasite host distribution and discover novel species. This has generated a signification amount of information, particularly on the diversity and host distribution; other aspects such as morphology, host distribution and medical significance have also been investigated. Amongst the four main groups (mites, fleas, ticks, lice), rat-borne mites have received the most attention with a particular emphasis on chiggers, due to their medical importance. More recent studies have examined the distribution of ectoparasites in rats from different habitat type simplicating a high prevalence of zoonotic species infesting rat populations. Despite being capable of transmitting dangerous pathogens to human, the health risks of rat-borne ectoparasites appear to be small with no serious outbreaks of diseases recorded. Although an extensive number of works have been published, there remain gaps in knowledge that need to be addressed, such as, the distribution of under studied ectoparasite groups (listrophorids and myobiids), determining factors influencing infestation, and understanding changes to the population distribution over time.
\end{abstract}

Keywords: Ectoparasites, Host distribution, Mites, Ticks, Fleas, Lice

\section{Background}

Rats have successfully exploited a wide variety of habitats and environments throughout the world. In many places, commensal rodents have adapted to living in close association with humans, using human agriculture products and waste as their food resources and buildings as their homes. "You are never more than $6 \mathrm{ft}$ away from a rat" may be an urban myth, but demonstrates the intimate relationship between rats and human urban dwellers [1]. Rats, particularly species that live close to humans, play an important role in public health and the economy. Zoonotic diseases transmitted directly by rats through bites, urine and faeces include Leptospirosis [2], which affects 7-10 million people per year globally. However, perhaps more important is the indirect transmission of diseases that takes place through rat-borne ectoparasites such as the flea, Xenopsylla cheopis; the

\footnotetext{
* Correspondence: nsheena@um.edu.my

'Institute of Biological Sciences, Faculty of Sciences, University Malaya, 50603 Kuala Lumpur, Malaysia

Full list of author information is available at the end of the article
}

vector of causative agents, Yersinia pestis, responsible for the plague, and Rickettsia typhi, responsible for typhus [3].

Historically, collections and surveys of ectoparasites across the region now known as peninsular Malaysia, have been conducted to record and catalogue the various local rat-borne ectoparasite species [4-8], to determine their geographical distribution and host specificity [9-11], and in particular collect data regarding the incidence of medically significant species $[12,13]$. Since the 1940 s, a significant amount of data has been accumulated on diversity and host distributions of rat-borne ectoparasites but surveys have, for pragmatic reasons, mostly focused on restricted taxonomics groups (e.g. ticks [9]; fleas [14]) or limited localities or habitats [4,6-9,12,15-22]. In surveys, rat-borne ectoparasites are generally categorized into four major groups, i.e. mites, fleas, ticks, and lice. Rat-borne mites, a highly diverse and specialized group, are further divided into chiggers, mesostigmatid mites, listrophorids and myobiids. Other published works related to the ectoparasite surveys include 
(i) descriptions of new species [23-25] and other taxonomic analyses [26,27], (ii) studies of ectoparasite morphology [27-29] and habitat [30,31], (iii) seasonal variations in diversity $[17,32]$, and (iv) isolation of medically significant pathogens [33-35]. Other aspects such as lifecycle [36,37], and behaviour [38,39] have also been investigated but to a lesser degree.

Comprehensive surveys or reviews regarding rat-borne ectoparasites in peninsular Malaysia have seen commendable consistency in the frequency of published studies on the local rat-borne ectoparasite fauna since the early 1930's $[18,40-42]$ with the notable works in recent years $[21,22,43,44]$. Therefore, the objective of this review is to compile and correlate the available information on ectoparasite-host interactions and ectoparasite behaviour. This will lead to better perspectives on the epidemiology of related diseases as well as identify gaps in knowledge which may act to stimulate future studies.

\section{Review \\ Mites \\ Chiggers}

Following Gater's study in 1932 [42], scientific interest in rat-borne ectoparasites was ignited by a concerted effort from the late 1940's to early 1950's [43-45] to investigate the epidemiology of scrub typhus in the AsiaPacific Region. It was quickly established that chiggers (Arachnida: Trombiculidae), particularly Leptotrombidium deliensis, are the primary vectors for the disease. The incidences of chiggers were found to be closely associated with the presence of wild rats prompting subsequent studies to examine the ecological distribution of both chiggers and their hosts [16,37,45-47].

It soon became clear that chiggers from peninsular Malaysia are a uniquely ubiquitous and diverse group being reported in virtually every local general ratborne ectoparasite survey [6-8]. Walchiella oudemansi, Leptotrombidium deliense and Gahrliepia fletcheri are the more commonly observed species [37]. Chiggers then began to generate interest independently of their association with thypus and there was a sudden increase in reports on the local, often novel, species [48-50]. A substantial portion of the reports in the Malaysian Parasite series by the Institute for Medical Research have focussed on chiggers. The overwhelming collection of data concerning the morphology, ecology, hosts, behavior, population control and medical significance of local chiggers was incorporated into an important early review paper $[15,37,51]$. The summary of the presence of chiggers and its hosts are as described in Table 1.

\section{Mesostigmatid and other mites}

Among the rat-borne ectoparasites groups; rat mites (Arachnida) have received the most attention. Rat mites are a highly diverse and specialized group that includes chiggers (see above), mesostigmatids, listrophorids and myobiids. Major general works include Domrow and Nadchatram [10], Domrow [25] and Ismail et al. [11]. Lately, attention has begun to shift from chiggers toward the mesostigmatid mites $[11,13]$, another similarly widespread and species-rich group. These recent studies have accumulated information on host distribution, diversity and morphological characteristics. Laelaps echidninus, Laelaps nutalli, Laelaps sedlaceki L. turkestanicus $L$. sanguisugus and Longolaelaps whartoni are some of the more common rat-borne mesostigmatids in peninsular Malaysia [21,44]. Other less common species include Haemolaelaps gallinarii [52]; Haemolealaps argentiventer [53]; Haemogamasus liberiensus and Tricholealaps vitzthumi $[54,55]$.

In contrast, information on the distribution and prevelance of the other two rat mite groups, the listrophorids (Table 2) and myobiids (Table 3) is still preliminary with only eighteen and ten species having been recorded respectively. This is possibly due to the fact that these ectoparasites have shown little or no medical and ecological significance. Listrophorids infestations among the local wild rats have only been reported occasionally $[4,5]$. Even less has been reported about diversity and distribution of rat myobiids [4]. Presently, two publications by Fain and collagues $[56,57]$ remain the definitive references on the local rat-borne listrophorids and myobiids.

\section{Fleas}

Documentation of rat-borne fleas (Insecta: Siphonaptera) and ticks (Arachnida: Ixodida) also began during the 1940s and 1950s [58], and continued intermittently over the following years $[13,18,21,41]$. There has only been two long-term surveillance studies on the incidence of fleas among local small mammals [14,59]. Both studies recognized Xenopsylla cheopis as the most prevalent rat-borne flea in the region. Zahedi et al. [60] showed that urban rat populations had a higher flea index compared to semi-urban rat populations. They also reported $6 \%$ of the rats trapped in the city harboured the cat flea, Ctenocephalides felis [60]. Other species include Stivalius ahalae [6], Rothschildiana smiti [23] and interestingly, Xenopsyllaastia, a common cosmopolitan species, has been observed only once [3]. Stivalius jacobsoni on Niniventer rapit, Stivalius klossi on Niniventer cremoriventer and Paraceras sp. on Maxomys edwardsi have been reported by Traub [58].

\section{Ticks}

The first major study on rat-borne ticks from peninsular Malaysia was conducted by Kohls [9], who compiled a 
Table 1 Chiggers (Acari, Prostigmata, Trombiculidae) in peninsular Malaysia

\section{Species}

A. (A.) audyi (Womersley, 1952)

A. (A.) calcar Nadchatram and Domrow, 1964

A. (A.) ctenacarus Domrow, 1962

A. (A.) daria (Traub and Audy, 1954)

A. (A.) dentata Nadchatram and Domrow, 1964

A. (A.) globosa Nadchatram and Domrow, 1964

A. (A.) indica (Hirst, 1915)

Cheladonta (Susa) debilis (Gater, 1932)

Doloisia alticola (Audy and Nadchatram, 1957)

D. brachypus (Audy and Nadchatram, 1957)

D. browningi (Audy and Nadchatram, 1957)

D. domrowi (Audy and Nadchatram, 1957)

D. harrisoni (Audy and Nadchatram, 1957)

D. intermedia (Audy and Nadchatram, 1957)

D. jadini (Audy and Nadchatram, 1957)

D. owenevansi (Audy and Nadchatram, 1957)

D. varmai (Audy and Nadchatram, 1957)

Gahrliepia (G.) cetrata Gater, 1932

G.(G.) ciliata Gater, 1932

G.(G.) fletcheri Gater, 1932

G.(G.) insigne Womersley, 1932

G.(G.) neterella Traub and Morrow, 1955

G.(G.) ornata Womersley, 1952

G.(G.) picta Traub and Morrow, 1955

G.(G.) rutila Gater, 1932

G.(G.) tessellata Traub and Morrow, 1955

Gahrliepia (Schoengastiella) argalea Traub and Morrow, 1957

G.(S.) arona Traub and Audy, 1954

G. (Walchia) alpestris Traub and Evans, 1957

G. (W.) brennani Womersley, 1952

G. (W.) cupa Traub and Evans, 1957

G. (W.) cuspidata Traub and Evans, 1957

G. (W.) disparangus (Oudemans, 1910)

G. (W.) enode (Gater, 1932)

G. (W.) ewingi (Fuller, 1949)

G. (W.) lewthwaitei Gater, 1932

G. (W.) pingue (Gater, 1932)

G. (W.) rustica Gater, 1932

G. (W.) simulata Traub and Evans, 1957

G. (W.) turmalis Gater, 1932

G. (W.) ventralis Womersley, 1952

Heaslipia gateri (Womersley and Heaslip, 1943)

Helenicula mutabilis (Gater, 1932)

\section{Host}

Lenothrix canus, L. sabanus, R.t. jalorensis

Rat

R.t.jalorensis

Rat

Rat

Tree and ground rats

R.r.diardii, R.t.jalorensis

Rattus annandalei, R.t. jalorensis, L. sabanus, S. muelleri

M. alticola

M. surifer

B. bowersi

M. surifer

B. bowersi, L. sabanus, R.t. jalorensis, M. rajah, Maxomys whiteheadi, S. muelleri M. surifer

B. bowersi, L. edwardsi, L. sabanus, M. rajah

M. rajah

B. bowersi, M. rajah, M. whiteheadi

L. edwardsi, L. sabanus, S. muelleri

Rat

R. argentiventer, Rattus exulans, L. sabanus, S. muelleri

B. bowersi, L. edwardsi, L. sabanus, M. alticola, M. rajah

B. bowersi, L. edwardsi, L. sabanus,

L. sabanus, S. muelleri

B. bowersi, L. sabanus,

B. bowersi, L. edwardsi, L. sabanus, R.t. jalorensis,

Rat

L. sabanus

M. whiteheadi, S. muelleri

B. bowersi

Rat

M. surifer

L. sabanus

M. whiteheadi

S. muelleri

M. whiteheadi

M. rajah, M. whiteheadi, R. argentiventer, R. exulans, R.t. jalorensis

L. sabanus, L. edwardsi, M. rajah, M. whiteheadi, Niviventer rapit

L. sabanus, M. surifer

B. bowersi, L. edwardsi, M. alticola

B. bowersi, L. edwardsi, L. sabanus

B. bowersi

Rat

L. sabanus, S. muelleri 
Table 1 Chiggers (Acari, Prostigmata, Trombiculidae) in peninsular Malaysia (Continued)

\begin{tabular}{ll}
\hline Kayella novita (Audy and Womersley, 1957) & M. rajah \\
Schoutedenichia bisetosa Domrow, 1962 & Rat \\
S. vercammeni Audy, 1956 & L. sabanus \\
\hline
\end{tabular}

host-parasite checklist and a comprehensive taxonomic key. The study provided the basis for further investigations into the host distribution of rat-borne ticks in the region $[61,62]$. Extensive collections have revealed wild terrestrial rats to be a common, perhaps preferred, host for immature ticks (e.g. Amblyomma spp., Haemphysalis spp. and Dermacentor spp.), while Ixodes granulatus was the only adult tick found on rats [9-12,16,17,63]. Interestingly, Nadchatram et al., 1966 recorded Amblyomma helvoluma species usually found on reptiles on a rat, Leopoldamys sabanus [16]. However, difficulties identifying immature rat-borne ticks beyond the genus level have hindered efforts to associate tick infestations with the behavioral and ecological data on their hosts.

\section{Lice}

Studies concerning rat-borne lice have focused on morphology for taxonomic identification and phylogenetics [13,28,64]. Presently, Hoplopleura pacifica, $H$. dissicula, $H$. pectinata and Polyplax spinulosa have been recorded from peninsular Malaysia [21,65]. Lice have only been included occasionally in the general rat-borne ectoparasites surveys $[6,7,18,21,22,41]$.

\section{Breaking the taxonomic boundaries}

Early rat-borne ectoparasite surveys showed a propensity to limit their focus on specific groups, as evident in the review by Audy [15]. As a result, the overall rat-borne ectoparasite community has been largely neglected and

Table 2 Listrophoroides Hirst, 1923 (Acari, Astigmata, Atopomelidae) of rats in peninsular Malaysia

\begin{tabular}{|c|c|c|}
\hline Species & Host & Locality \\
\hline Listrophoroides (Listrophoroides) biexcavatus (Fain, 1979) & Maxomys rajah & Besut, Terengganu Mentakab, Pahang \\
\hline \multirow[t]{2}{*}{ L. (L.) borneoensis (Fain, 1970) } & Sundamys muellari & Ulu Langat, Selangor \\
\hline & Rattus argentiventer & Ulu Jenderam, Selangor \\
\hline L. (L.) brachypyx (Fain, 1974) & Rattus tiomanicus & Bukit Lanjan, Selangor \\
\hline L. (L.) cocoensis (Fain, 1976) & Maxomys rajah & Besut, Terengganu, Mentakab, Pahang. \\
\hline L. (L.) eudrilus (Fain, 1976) & Maxomys surifer & Besut, Terengganu Perak \\
\hline L. (L.) hemistriatus (Fain, 1976) & Maxomys surifer & Ulu Setia, Terengganu \\
\hline L. (L.) hongkongensis cremoriventer (Fain, 1976) & Niviventer cremoriventer & Bukit Besar, Besut, Terengganu \\
\hline L. (L.) maculatissimus (Fain, 1979) & Maxomys rajah & Besut, Terengganu, Terengganu; Mentakab, Pahang \\
\hline \multirow[t]{2}{*}{ L. (L.) neobifidus (Fain, 1979) } & Maxomys rajah & Bukit Lanjan, Selangor \\
\hline & Maxomys surifer & Ulu Setia, Terengganu \\
\hline \multirow[t]{2}{*}{ L. (L.) pahangi (Fain, 1974) } & Leopoldmys edwardsi & Ulu Langat, Selangor; Mt Brinchang, Cameron Highland, Pahang \\
\hline & Leopoldmys sabanus & Gunong Benom, Pahang; Terengganu \\
\hline L. (L.) ptilocereus (Fain, 1970) & Sundamys muellari & Ulu Langat, Selangor \\
\hline L. (L.) rajah (Fain, 1974) & Maxomys rajah & Ulu Setia, Terengganu. \\
\hline L. (L.) taxophallus (Fain, 1976) & Maxomys surifer & Ulu Setia, Terengganu \\
\hline L. (L.) uluensis (Fain, 1979) & Maxomys surifer & Ulu Setia, Terengganu \\
\hline \multirow[t]{3}{*}{ L. (Marquesania) cucullatus (Trouessart 1893) } & Rattus argentiventer & Ulu Jenderam, Selangor \\
\hline & Rattus exulans & Ulu Jenderam, Selangor \\
\hline & Rattus t. jalorensis & Bukit Lanjan, Selangor \\
\hline \multirow[t]{3}{*}{ L. (M.) lativentris (Fain, 1981) } & Sundamys muellari & Terengganu; Gombak \\
\hline & & Forest Reserve, Selangor \\
\hline & & Bukit Lanjan, Selangor \\
\hline L. (M.) sculpturatus (Fain, Nadchatram and Lukoschus 1981) & Sundamys muellari & Selangor \\
\hline
\end{tabular}


Table 3 Myobiidae (Prostigmata) from rats in peninsular Malaysia

\begin{tabular}{|c|c|c|}
\hline Species & Host & Locality \\
\hline \multirow[t]{2}{*}{ Radfordia (Radfordia) ensifera (Poppe, 1896) } & Rattus rattus diardii & Gombak Forest Reserve, Selangor \\
\hline & Rattus tiomanicus jalorensis & Bukit Lanjan Forest Reserve, Selangor; Subang Forest Reserve, Selangor \\
\hline $\begin{array}{l}\text { R. (R.) ensifera jalorensis (Fain, Lukoschus } \\
\text { and Nadchatram, 1980) }\end{array}$ & Rattus tiomanicus jalorensis & Bukit Lanjan Forest Reserve, Selangor \\
\hline R. (R.) hornerae (Domrow, 1963) & Leopoldmys sabanus & Templar's Park, Selangor \\
\hline \multirow[t]{2}{*}{ R. (Rattimyobia) perakensis (Fain, 1973) } & Maxomys rajah & Bukit Lanjan Forest Reserve, Selangor; Kampong Awak, Temerloh, Pahang \\
\hline & Maxomys surifer & Perak \\
\hline R. (Rattimyobia) acinaciseta (Wilson, 1967) & Maxomys rajah & Bukit Lanjan Forest Reserve, Selangor; Mentakab, Pahang \\
\hline \multirow{2}{*}{$\begin{array}{l}\text { R. (Rattimyobia) pahangensis (Fain, Lukoschus } \\
\text { and Nadchatram, 1980) }\end{array}$} & Maxomys inas & \multirow[t]{2}{*}{ Mt. Brinchang, Cameron Highlands, Pahang } \\
\hline & Niniventer bukit & \\
\hline $\begin{array}{l}\text { R. (Rattimyobia) selangorensis (Fain, Lukoschus } \\
\text { and Nadchatram, 1980) }\end{array}$ & Maxomys whiteheadi & Subang Forest Reserve, Selangor \\
\hline $\begin{array}{l}\text { R. (Rattimyobia) subangensis (Fain, Lukoschus } \\
\text { and Nadchatram, 1980) }\end{array}$ & Maxomys rajah & Subang Forest Reserve, Selangor \\
\hline R. (Graphiurobia) chiropodomys (Fain, 1974) & Chiropodomys gliroides & Gombak Forest Reserve, Selangor \\
\hline $\begin{array}{l}\text { Myobia (Myobia) malaysiensis (Fain, Luoschus } \\
\text { and Nadchatram, 1980) }\end{array}$ & Chiropodomys gliroides & Gombak Forest Reserve, Selangor \\
\hline
\end{tabular}

the intercommunity population dynamics are poorly understood. Recently there have been attempts to redress the situation $[4,11,41]$.

Perhaps for pragmatic reasons, past researchers seemed content in focusing on cataloguing the ectoparasites' host distribution and describing novel species. The majority of reports are strictly short-term field observations and prevalence studies, and though several extensive, noteworthy works were produced $[9,28,48]$, the seemingly perfunctory approach has restricted further insights into the factors influencing the development, behaviour and transmission of rat-borne ectoparasite species. Additionally, besides for chiggers and ticks, there had been virtually no experimental investigations conducted on local rat-borne ectoparasites $[36,38,66]$. This may be due to the fact ratborne ectoparasites do not represent immediate zoonotic risks.

A study by Ho and Krishnasamy [12] warrants a special mention as a survey in which both the ectoparasite and endoparasite of small mammals from Taman Negara was recorded concurrently. Although the study was little more than a host-parasite list, it raises the issue of the probable links between concurrent rat-ecto and endoparasite infections, in which the ectoparasites may serve as intermediate hosts for certain helminthes.

\section{Identification and morphology}

Identification of rat-borne ectoparasites had thus far been entirely based on the morphological characteristics of the specimens using available keys and published reference manuals $[9,28,67]$. Morphological studies therefore placed an emphasis on in-depth and reliable descriptions of the local species and are often accompanied with detailed graphics [25,28]. Perhaps curiously, the most detailed morphological descriptions of the rat-borne ectoparasite fauna of peninsular Malaysia were those of ratborne lice and ticks while the morphology of rat myobiids and listrophorids from peninsular Malaysia have yet to be systematically and thoroughly described.

\section{Distribution and prevalence patterns}

Rat-borne ectoparasites have been reported from various habitats throughout peninsular Malaysia, including primary lowland forest [11,19], secondary forest [5], montane forests [29,68], cities [14,18], cultivated fields [69,70] and coastlines [31]. The majority of collections have been from primary rainforests but several studies have also conducted concurrent investigations of more than one habitat $[10,28,40]$.

These surveys have enabled comparions of the diversity of rat-borne ectoparasites from different habitats across peninsular Malaysia and revealed that generally, each ectoparasite species is restricted to a certain habitat [71-73]. For example, rat-borne fleas and lice were commonly recorded in urban areas but were rarely recorded anywhere else [60]. The rat-borne ectoparasite distribution is therefore assumed to be closely linked to the host species' habitat specialisation. Audy [27] remarked that for chiggers, "habitat-specificity may give an appearance of host-specificity, and occasionally it may not be possible to explain findings confidently by one explanation or the other". Similar thoughts were also expressed by several authors $[32,44,66,74]$ and while it may seem reasonable to assume that a degree of host 
specificity exists, its actual role, as well as the extent of its effects, still needs to be clarified.

The impact of human activities on the disease patterns of rat-borne infections has only been briefly remarked upon [66] and anthropogenic changes to the habitat of rats appear to have unpredictable consequences for the prevalence and distribution of rat-borne ectoparasites $[66,70,75,76]$. The severity and long-term effects are still largely unclear. Surveys in Taman Negara $[12,19,35]$ and Gombak Forest Reserve $[4,11]$ could provide the basis for long-term studies that would enable future researchers to detect changes in the diversity and intensity of rat ectoparasite infestations that may occur as a result of human impact. Traub and Wisseman [70] hypothesized that rats occupying permanent nests would exhibit higher mite burdens because mites, particularly mesostigmatids, are nest dwellers and that infestations are acquired during the hosts' time in the nest. The authors further speculated that spiny- furred rats provide a more conducive environment for mites, in contrast to softfurred and semi-spiny-furred hosts, thereby contributing to the supposed higher mites loads in such hosts. However, no studies have set out to futher test this hypothesis.

There have been no attempts to investigate the effects of the age and sex of hosts on ectoparasite burdens and transmission, but studies have indicated a link between host size and parasite abundance [32].

The effect of seasonal changes and rainfall on ectoparasite burdens have only been briefly explored. It has been hypothesized that dry conditions may have an adverse effect on chigger infestations [32,51]. Lim [17] was unable to conclusively demonstrate the association of rainfall with immature tick infestations, while Singh et al. [14] likewise did not observe any relationship between rainfall and flea indices. The altitudinal distribution of rat-borne ectoparasites has been investigated by Hoogstraal et al. [77] and Nadchatram [68], who found ticks were found in reasonable numbers at the higher altitudes, while chiggers were virtually absent. The actual effects of altitude on the distribution of rat-borne ectoparasites are however not readily apparent and warrant further study.

\section{Vectors of human diseases}

Rat ectoparasites have long been known to be capable of transmitting human diseases such as (i) scrub typhus, (ii) murine typhus, (iii) other types of typhus, (iv) the plague, (v) Bartonella and (vi) various viruses. In fact, the potential threat to public health has been the major justification for many studies [35].

(i) Scrub typhus, a rickettsial disease transmitted through the bite of an infected chigger, is arguably one of the more well-known diseases associated with the rat-borne ectoparasites in peninsular Malaysia. It is a common cause of fever in rural populations [78,79]. The distribution of scrub typhus has been extensively studied, and is generally associated with cultivated fields and secondary forests, and its epidemiology is linked to human behaviour and occupation [80]. Leptotrombidium deliensis, frequently found infesting wild rats living within or near the vicinity of agriculatural land and secondary forests, is the major vector for Orientia tsutsugamushi, the causative agent for the disease $[37,58]$. Other chigger species have also been implicated in maintaining and transmitting the disease $[35,81,82]$. An exhaustive and highly comprehensive review of scrub typhus and various related factors by Traub and Wisseman [51] concluded that chiggers of the subgenus Leptotrombidium associated with rats from the genus Rattus were able to penetrate new areas and habitats and diversify, and as the chiggers adapted to other hosts in the new regions, such mammals became secondarily involved in the ecology of the rickettsiosis.

(ii) Murine typhus, also known as urban typhus, is another rat-borne disease from the typhus group. The causative agent is Rickettsia typhi and infection can be transmitted from rats to humans though rat-borne fleas, Xenopsylla cheopis [83]. Murine typhus is still considered uncommon despite indications that the disease is more widespread than previously thought $[34,80,84]$.

(iii)There has been indications of a "jungle cycle" scrub typhus in peninsular Malaysia [51,58,85]. Cadigan Jr et al. [86] and Robinson et al. [87] linked the length of residence in forested areas with the infection rate among humans. Though the existence of other scrub typhus strains remains in question, the risks of typhus from primary forests is estimated to be considerably less compared to areas typically associated with the disease [35]. Occurrences of tick typhus or spotted fever group rickettsiae (SFGR), another rickettsioses associated with rat-borne ectoparasites, have also been recorded in peninsular Malaysia [33,80,84]. Marchette [33] implicated Ixodes granulatus and Dermacentor auratus in their transmission.

(iv)Rat-borne fleas are also known vectors of Yersinia pestis, the bacterial agent of plague. While there has been no outbreaks in recent years in peninsular Malaysia, plague is endemic in other Southeast Asian countries, including Indonesia [88,89], Thailand [90], Vietnam [91] and Myanmar [92]. The first case of plague in Malaysia occurred in Penang 
in 1896 and the most recent case was in Perak in 1928 [3].

(v) The occasional rat-borne flea (Ctenocephalides felis) and rat-borne tick (Ixodes granulatus) are also often implicated in the natural maintenance of various species of Bartonella. A recent study observed five Bartonella species (Bartonella tribocorum, B. rattimassiliensis, B. coopersplainsensis B. elizabethae and B. queenslandensis) circulating in the rat population in Kuala Lumpur [93].

(vi) Rat-bourne ticks are also known hosts of the Langat Virus Langat Virus [94], the forest cycle of Q-fever [33], and the Lanjan Virus [95]. Lanjan virus has been isolated from immature Dermacentor $[95,96]$.

Aside from harbouring and transmitting dangerous pathogens, the ectoparasites themselves are also capable of causing skin irritations for humans. Among the local rat-borne ectoparasites, mesostigmatids i.e. Ornithonyssus bacoti, Laelaps echidninus and Laelaps nuttalli, have been reported as attacking humans, resulting in varying degrees of dermatitis $[67,97]$. Chiggers are also known to occasionally cause irritations commonly known as scrub itch [12].

Human health concerns associated with chiggers are rural in nature, confined to secondary forest and plantations i.e. areas with low population density. Although the threat of chiggers on human health is fortunately limited, its impact on ecotourism and other daily human activities are often overlooked. Rat-borne fleas appear to pose the highest health risk to humans as their rat hosts and distribution are concentrated within or near highdensity human habitations but there has been no serious outbreaks of diseases associated with rat-borne fleas. Likewise the medical significance of rat-borne ticks on public health is presently strictly academic. Despite being shown to be capable of harbouring several dangerous pathogens, there has yet to be any verified reports of tick related infections in peninsular Malaysia. The other ectoparasites groups, the rat-borne lice, myobiids and listrophorids also are presently of no known medical importance [98]. Further investigations should be initiated to update and verify their significance to public health.

To summarize, the collective impact of the local ratborne ectoparasites on public health is presently low, perhaps even negligible. However, the above studies have shown that these ectoparasites harbour a number of serious pathogens, and could potentially become major health risks in the future. To circumvent this, population dynamics of rat-borne ectoparasites and the epidemiology need to be better understood.

\section{Major gaps in present knowledge of rat-borne cctoparasites of peninsular Malaysia Quantitative data and statistical analyses}

Despite consistent attempts to survey and catalogue the various rat-borne ectoparasite species throughout the region, the collection of quantitative data and statistical analysis of the infestations have been surprisingly inadequate. Though a few surveys did calculate the prevalence of the infestations $[4,5,18]$ and mean intensity values [17,32], measures of variability seem mostly to have been disregarded. With the exception of the work of Ismail et al. [11], diversity and aggregation indices, commonly found in the more recent international parasitological publication, have failed to be incorporated into the peninsular Malaysia investigations. Most surveys conducted have been little more than a host-parasite checklists.

1. Interspecific and intraspecific interactions Inter- and intraspecific interactions of different ectoparasite species have never been fully explored. As it is commonly observed that wild terrestrial rats often harbour concurrent ectoparasites infections it would therefore be of great interest to observe how these ectoparasites interact and affect one another within the limited space (e.g. crowding effects, competition, etc.).

2. Natural resistant of hosts While briefly mentioned in Boese's study [99], the pathological aspects of ectoparasite infestation of rats are poorly documented. Virtually no information is available on natural resistance and immunological reactions of the host with ectoparasite infestations.

3. Niche specialization

There have been observations that certain chiggers species from peninsular Malaysia occupy a specific site within their hosts, such as the nasal cavities [100]. These unique microhabitats have since become an important characteristic for species identification $[26,101]$. The existence of site specificity is intriguing and reflects the degree of interspecific interactions that may occur in concurrent infestations. Surprisingly however, the phenomenon was not investigated further and it is not known if the species of other ectoparasite groups exhibit a similar behaviour.

4. Morphology and identification Most studies carried out by scientists in peninsular Malaysia adopt the conventional method for ectoparasite identification i.e using morphological keys. Using this method only experienced taxonomists are able to distinguish species reliably. The availability of molecular biology as a tool to 
assist identification has become common place [102], however, there is neither interest nor urgency among researchers to conduct molecular characterization on the local rat-borne ectoparasite species.

\section{Conclusions}

Considerable attention has been given towards the ectoparasites of the wild, terrestrial rats in peninsular Malaysia. The majority of rat-borne ectoparasitological studies were field surveys and collections of specimens from across the region although other aspects such as morphology, host distribution and medical significance have also been investigated. Local rat-borne ectoparasite studies often focus on selected groups, particularly chiggers due to their impact on human health, although in recent years attention has slowly shifted towards the overall ectoparasite diversity. Studies on rat-borne ectoparasites have been invaluable in the fields of ecology and public health.

Despite the number of studies that have been published, a number of related issues have to be addressed. Distribution patterns of certain rat-borne ectoparasites still remains unknown. Factors influencing infestations as well as changes to the population distribution over time are also poorly understood. Additionally, the quantitative aspects of ectoparasite infestations have also been largely neglected. It is therefore vital for researchers in the field to redevelop and reprioritize their focus towards these lesser known aspects.

\section{Competing interests}

The authors declare that they have no competing interests.

This review was put together with the assistance of The University Malaya Research Grants FS285/2008C and FP005/2008C.

\section{Authors' contributions}

SNMZ and SAASK performed the systematic literature review. SNMZ conceived and wrote the review with assistance from JJ, NMAA, JJW, KAB, and PS. All authors read and approved the final manuscript.

\section{Acknowledgements}

The authors would like to thank the University of Malaya for the support of this work.

\section{Author details \\ ${ }^{1}$ Institute of Biological Sciences, Faculty of Sciences, University Malaya, 50603 Kuala Lumpur, Malaysia. ${ }^{2}$ Yayasan Peneraju Pendidikan Bumiputera, 15-1, Mercu UEM, Jalan Stesen Sentral 5, Kuala Lumpur Sentral, 50470 Kuala Lumpur, Malaysia. ${ }^{3}$ Department of Parasitology, Faculty of Medicine, University of Malaya, 50603 Kuala Lumpur, Malaysia. ${ }^{4}$ Museum of Zoology, Institute of Biological Sciences, Faculty of Sciences, University Malaya, 50603 Kuala Lumpur, Malaysia. ${ }^{5}$ Institute for Medical Research, Jalan Pahang, 50588 Kuala Lumpur, Malaysia.}

Received: 22 July 2014 Accepted: 12 April 2015

Published online: 29 April 2015

\section{References}

1. Mokoena T. Urban Myths: Are you never more than $6 \mathrm{ft}$ from a rat in a city? The Guardian Online. Available at http://www.theguardian.com/cities/2014/ feb/13/urban-myths-6ft-from-a-rat. 2014.
2. Thayaparan S, Robertson I, Fairuz A, Suut L, Abdullah M. Leptospirosis, an emerging zoonotic disease in Malaysia. Malays J Pathol. 2013;35(2):123-32.

3. Anon. Fifty years of Medical Research in Malaya. Plague. Editors: Field, J.W. Green, R. \& Byron, F.E. Stud Inst Med Res Fed Malaya. 1950;25:243-52.

4. Shabrina M. Ectoparasites of small mammals trapped at the Ulu Gombak Forest, Selangor Darul Ehsan. J Wild life Parks. 1990;10:9-17.

5. Shabrina MS, Salleh I. A study on the parasitofauna of rodents and bats at Serting, Negeri Sembilan. J Wildlife Parks. 1995;15:33-42.

6. Mariana A, Zuraidawati Z, Ho TM, Mohd Kulaimi B, Saleh I, Shukor MN, et al. A survey of ectoparasites in Gunung Stong Forest Reserve, Kelantan, Malaysia. Southeast Asian J Trop Med Public Health. 2005;36:25-31.

7. Mariana A, Zuraidawati Z, Ho TM, Kulaimi BM, Saleh I, Shukor MN, et al. Ticks (Ixodidae) and other ectoparasites in Ulu Muda Forest Reserve, Kedah, Malaysia. Southeast Asian J Trop Med Public Health. 2008:39:496-506.

8. Mariana A, Mohd Kulaimi B, Halimaton I, Suhaili ZA, Shahrul-Anuar MS, Nor Zalipah M, et al. Acarine ectoparasites of Panti Forest Reserve in Johore. Asian Pac J Trop Biomed. 2011;1:1-5.

9. Kohls GM. Malaysian parasites. XVIII. Ticks (Ixodoidea) of Borneo and Malaya. Stud Inst Med Res Fed Malaya. 1957;28:65-94.

10. Domrow R, Nadchatram M. Two field collections of Malayan ticks and mites. Malay Nat J. 1963;17:145-64.

11. Ismail S, Omar B, Sulaiman S, Sulaiman J, Zolkaflee Z. Notes on the ectoparasites of rodents from the Ulu Gombak Forest Reserve, Selangor. Trop Biomed. 2003;20(2):159-63.

12. Ho TM, Krishnasamy M. Ectoparasites acari and endoparasites of small mammals in Taman Negara. J Wildlife Parks. 1990;10:54-61.

13. Chuluun B, Mariana A, Ho T, Mohd Kulaimi B. Research Note A preliminary survey of ectoparasites of small mammals in Kuala Selangor Nature Park. Trop Biomed. 2005;22(2):243-7.

14. Singh Kl, Ambu S, Krishnasamy M, Rosli R, Jeffery J. Surveillance of fleas from small mammals from Kuala Lumpur. Trop Biomed. 1995;12:17-21.

15. Audy J. Malaysian Parasites - XXXIV. A review of the literature. Stud Inst Med Res Malaya. 1957;28:427-47

16. Nadchatram M, Damrow R, Ng CK. Parasitic Acarina of the mammals. Bull Nat Mus Singap. 1966;34:129-40.

17. Lim BL. Host-relationships and seasonal abundance of immature ticks (Haemaphysalis spp. and Dermacentor spp.) in primary and mixed secondary rainforests in West Malaysia. Southeast Asian J Trop Med Public Health. 1972;3(4):605-12.

18. Zahedi M, Jeffery J, Krishnasamy M, Bharat V. Ectoparasites fauna of Rattus rattus diardii from an urban and semi urban environment. J Malays Soc Health. 1984;4(2):25-7.

19. Ho TM, Nadchatram M, Salleh I. Ectoparasites of rodents and bats from Taman Negara. Trop Biomed. 1985;2:193-5.

20. Mariana A, Ho T, Saleh I, Indudharan R. Species distribution of ticks in two localities in Kelantan. Trop Biomed. 1996;13:185-8.

21. Paramasvaran S, Sani RA, Hassan L, Krishnasamy M, Jeffery J, Oothuman P, et al. Ectoparasite fauna of rodents and shrews from four habitats in Kuala Lumpur and the states of Selangor and Negeri Sembilan, Malaysia and its public health significance. Trop Biomed. 2009;26(3):303-11.

22. Madinah A, Fatimah A, Mariana A, Abdullah MT. Ectoparasites of small mammals in four localities of wildlife reserves in Peninsular Malaysia. Southeast Asian J Trop Med Public Health. 2011;42(4):803-13.

23. Traub R. Malaysian Parasites XVII. Four new species of fleas (Siphonaptera). Stud Inst Med Res Fed Malaya. 1957;28:35-64.

24. Traub R. Muesebeckella, a new genus of flea from New Guinea, with notes on convergent evolution (Siphonaptera: Pygiopsyllidae). Entomol Soc Wash Proc. 1969;71:374-96.

25. Domrow R. Seven new species of Laelaps from Malaysia(Acarina: Laelaptidae). Acarologia. 1962;4:503-19.

26. Audy J. Laurentella, a new subgenus of trombiculid mites, with notes on biology and medical importance. Bull Raffles Mus. 1956;28:5-26.

27. Audy J. Malayan trombiculid mites. 2. Naked-eye observations on attached chiggers, with a simple checklist of Malayan species, and details of preferred hosts. Bull Raffles Mus. 1956;28:86-101.

28. Johnson PT. The Hoplopleurid lice of the Indo-Malayan subregion (Anoplura: Hoplopleuridae). Entomol Soc Am. 1964;4(3):68-102.

29. Keirans JE, Clifford GM, Hoogstraal H. Description of the male and immature stages of Ixodes werneri Kohls (Acarina: Ixodidae), a parasite of Rattus in mountains of Palawan, Malaya and Java. J Med Entomol. 1970;7(5):605-8. 
30. Hubert AA, Baker HJ. Studies on the habitats and population of Leptotrombidium (Leptotrombidium) akamushi and L. (L) deliensis in Malaya (Acarina: Trombiculidae). Trop Med Hyg. 1963;78(2):131-42.

31. Upham RW, AA JH, Phang OW, Yusof BM, Rapmund G. Distribution of Leptotrombidium (Leptotrombidium) arenicola (Acarina: Trombiculidae) on the ground in West Malaysia. J Med Entomol. 1971;8(4):401-6.

32. Roberts LW, Muul I, Robinson DM. Numbers of Leptotrombidium (Leptotrombidium) deliense (Acarina: trombiculidae) and prevalence of Rickettsia tsutsugamushi in adjacent habitats of peninsular Malaysia. Southeast Asian J Trop Med Public Health. 1977;8(2):207-13.

33. Marchette NJ. Rickettsioses (Tick typhus, Q-fever, Urban Typhus) in Malaya. J Med Entomol. 1966;2(4):339-71.

34. Brown G, Dohany A, Shirai A, Gan E, Huxsoll D. Murine typhus in a Malaysian village. Southeast Asian J Trop Med Public Health. 1977;8(1):99-103.

35. Dohany A, Lim B, Robinson D, Huxsoll D. An ecological study of Rickettsia tsutsugamushi in the primary forest of Taman Negara, Peninsular Malaysia. J Med Entomol. 1980;17(1):35-9.

36. Nadchatram M. Malaysian Parasites-XLVIII- Notes on rearing Malayan ixodid ticks (Acarina: Ixodidae) with special reference to Ixodes granulatus and Amblyomma geoemydae (Cantor). Stud Inst Med Res Fed Malaya. 1960;29:217-24.

37. Nadchatram M. Correlation of habitat, environment and color of chiggers, and their potential significance in the epidemiology of scrub typhus in Malaya (Prostigmata: Trombiculidae). J Med Entomol. 1970;7(2):131-44.

38. Harrison JL. Malaysian parasites-X-Feeding times of trombiculid mites. Stud Inst Med Res. 1953;26:171-83.

39. Kundin WD, Nadchatram M, Keong A. Notes on the duration of attachment of certain Malaysian trombiculid mite larvae. J Med Entomol. 1972;9(6):558-9.

40. Audy J, Harrison J. Malaysian parasites- I- collections made in Malaya by the Colonial Office Scrub Typhus research unit. Stud Inst Med Res. 1953;26:1-22.

41. Shabrina MS, Saharudin A, Refaee H. Ectoparasite of small mammals from Bukit Lanjan and Air Hitam Forest Reserves, Selangor. J Wildlife Parks. 1989;8:31-4.

42. Gater BAR. Malayan Trombidid Larvae Part I. (Acrina: Trombididiidae) with descriptions of seventeen new species. Parasitology. 1932;24:143-74.

43. Nur Syazana MT, Mohd Zain SN, Jeffery J. Biodiversity and macroparasitic distribution of the wild rat population of Carey Island, Klang. Trop Biomed. 2013;30(2):199-210.

44. Madinah A, Abang F, Mariana A, Abdullah M, Mohd-Azlan J. Interaction of ectoparasites-small mammals in tropical rainforest of Malaysia. Community Ecol. 2014;15(1):113-20

45. Philip CB, Traub R, Smadel JE. Chloramphenicol (Chloromycetin) in the chemoprophylaxis of scrub typhus (tsutsugamushi disease) - epidemiological observations on hyperendemic areas of scrub typhus in Malaya. Am J Trop Med Hyg. 1949;50:63-74.

46. Audy J, Harrison J. A review of investigations of mite typhus in Burma and Malaya, 1945-1950. Trans R Soc Trop Med Hyg. 1951;44(4):371-404.

47. Nadchatram M. Natural History of the Genus Leptotrombidium (Acari: Trombiculidae) with Reference to Scrub Typhus. In: Griffiths DA, Bowman CE, editors. Acarology VI. Chichester, England: Ellis Horwood Limited; 1984. p. 1107-13.

48. Audy J, Womersley H. Malaysian parasites, XXIX. New species of Oriental and Australian Trombiculidae (Acarina). Stud Inst Med Res. 1957;28:359-82.

49. Traub R, Evans TM. Stud Inst Med Res. 1957;28:297-358

50. Traub R, Morrow ML. Malayan Parasites-XXV- Descriptions and records of some Southeast Asian chiggers of the genus Gahliepia (Acarina: Trombiculid). Stud Inst Med Res. 1957;28:169-86.

51. Traub R, Wisseman CL. The ecology of chigger-borne rickettsiosis (scrub typhus). J Med Entomol. 1974;11(3):237-303.

52. Grokhovskaya I, Huan-Hoe N. Gamasid mites of North Vietnam, Part 2. Zool Zhurnal. 1961:40:1633-46.

53. Baker E, Traub R, Evans T. Indo-Malayan Haemolaeiaps, with descriptions of new species (Acarina: Laelaptidae). Pac Insects. 1962;4(1):91-100

54. Mariana A, Kulaimi BM, Halimaton I, Ho TM, Saleh I, Zuraidawati Z, et al. 6 Siri Kepelbagaian Biologi Hutan. In: Shahruddin Ml, editor. Fauna ektoparasite di altitud berbeza di Hutan Simpan Gunung Jerai, Kedah: Pengurusan, Persekitaran Fizikal dan kepelbagaian Biologi. Malaysia: Jabatan Perhutanan Semenanjung Malaysia; 2006.

55. Mariana A, Zuraidawati Z, Ho TM, Kulaimi BM, Saleh I, Shukor MN, et al. 7 Siri Kepelbagaian Hutan. In: Huda A, editor. Gunung Mandi Angin, Terengganu:
Pengurusan, Persekitaran Fizikal, Kepelbagaian Biologi \& Pelancongan Ekologi. Malaysia: Jabatan Perhutanan Semenanjung Malaysia; 2006.

56. Fain A. Classification and geographical distribution of Listrophoroide. Proc 3rd Int Congr Acarol. 1971:1971:411-4.

57. Fain A, Lukoschus F, Nadchatram M. Malaysian parasitic mites II. Myobiidae (prostigmata) from rodents. Int J Acarol. 1980;6:109-20.

58. Traub R. Notes on Indo-Malayan fleas, with descriptions of new species. Proc Entomol Soc Wash. 1950:52:109-43.

59. Singh Kl. Survey for vectors of plague at the refugee camp, Pulau Bidong, Kuala Terengganu. J Malays Soc Health. 1990;8(1):43-6.

60. Zahedi M, Jeffery J, Krishnasamy M, Bharat V. Ectoparasites of Rattus rattus diardii from Kuala Lumpur City Malaysia. Proc 2nd Int Conf Urban Pest. 1996;1996:437-9.

61. Audy J, Nadchatram M, Lim B. Malaysian parasites - XIIX - host distribution of Malayan ticks (Ixodoidea). Stud Inst Med Res Malaya. 1960;29:225-46.

62. Hoogstraal H, Trapido H, Kohls GM. Southeast Asian Haemaphysalis ticks (Ixodoidea, Ixodidae). H.(Kaiseriana) papuana nadchatrami spp. n. and redescription of H.(K.) semermis Neumann. J Parasitol. 1965:51(3):433-51.

63. Trevor NP, James EK. Ticks of the genus Ixodes in South-east Asia. Trop Biomed. 1994;11:123-34.

64. Johnson PT. Some Anoplura of the Oriental region. A study of Hoplopleura pacifica Ewing and allies. J Med Entomol. 1972;9(3):219-27.

65. Madinah A, Mariana A, Fatimah A, Abdullah M. Research Note A preliminary field survey of ectoparasites of rodents in urban park, Sarawak, Malaysian Borneo. Trop Biomed. 2013;30(3):1-5.

66. Harrison JL. The effects of withdrawal of the host on populations of trombiculid mites. Bull Raffles Mus. 1956;28:112-9.

67. Nadchatram M, Ramalingam S. Dermatitis caused by Ornithonyssus bacoti (Hirst, 1913). Southeast Asian J Trop Med Public Health. 1974;5(1):150.

68. Nadchatram M. The Gunong Benom Expedition, 1967. 9. A collection of chiggers from Gunong Benom (Prostigmata: Trombiculidae). Bull Br Mus Nat Hist Zool. 1972;4:189-98.

69. Traub R, Frick LP. Chloramphenicol (Chloromycetin) in the chemoprophylaxis of scrub typhus (Tsutsugamushi Disease) V. Relation of number of vector mites in hyperendemic areas to infection rates in exposed volunteers. Am J Epidemiol. 1950;51:242-7.

70. Traub R, Wisseman Jr CL. Ecological considerations in scrub typhus: 1. Emerging concepts. Bull World Health Organ. 1968;39(2):209-18.

71. Lim B-L. Distribution, relative abundance, food habits, and parasite patterns of giant rats (Rattus) in West Malaysia. J Mammal. 1970;51(4):730-40.

72. Muul I, Liat L. Habitat distribution and ectoparasites of small mammals in Sarawak. Sarawak Mus J. 1974;20(1972):359-66.

73. Syed-Arnez ASK, Mohd Zain SN. A study on wild rats and their endoparasite fauna from the Endau Rompin National Park, Johor. Malays J Sci. 2006;25(2):19-39.

74. Mohr CO. Relation of ectoparasite load to host size and standard range. J Parasitol. 1961;47:978-84.

75. Harrison JL. The effects of grassfire on populations of trombiculid mites. Bull Raffles Mus. 1956;28:102-11

76. Traub R, Wisseman CL. Diminution in the endemicity of scrub typhus with the passage of time. J Med Entomol. 1972;9(6):590-1.

77. Hoogstraal H, Lim BL, Nadchatram M, Anastos G. Gunong Benom Expedition, 1967. 8. ticks (Ixodidae) of Gunong Benom and their altitudinal distribution, hosts and medical relationships. Bull Br Mus Nat Hist Zool. 1972;23:167-86.

78. Brown GW, Robinson DM, Huxsoll DL. Serological evidence for a high incidence of transmission of Rickettsia tsutsugamushi in two Orang Asli settlements in Peninsular Malaysia. Am J Trop Med Hyg. 1978;27(1):121-4.

79. Brown GW, Shirai A, Jegathesan M, Burke DS, Twartz JC, Saunders JP, et al. Febrile illness in Malaysia-an analysis of 1,629 hospitalized patients. Am J Trop Med Hyg. 1984;33(2):311-5.

80. Tay ST, Muniady K, AS K, SC S, Ho TM, Rohani MY, et al. Seroepidemiologic survey of Orientia tsutsugamushi, Rickettsia typhi, and T1118 spotted fever group rickettsiae in rubber estate workers in Malaysia. Am J Trop Med Hyg. 1999:61(1):73-7.

81. Traub R, Wisseman Jr CL. Ecological considerations in scrub typhus: 2. Vector species. Bull World Health Organ. 1968:39(2):219-30.

82. Rapmund G, Dohany AL, Manikumaran C, Chan TC. Transovarial transmission of Rickettsia tsutsugamushi in Leptotrombidium (Leptptrombidium) arenicola Traub (Acarina: Trombiculidae). J Med Entomol. 1972;9(1):71-2. 
83. Lewthwaite R, Hodgkin EP, Savoor SR. The Typhus Group of Diseases in Malaya. Part VI: The Search for Carriers. Br J Exp Pathol. 1936;17(4):309-17.

84. Tay ST, Ho TM, Rohani MY, Devi S. Antibodies to Orientia tsutsugamushi, Rickettsia typhi and spotted fever group rickettsiae among febrile patients in rural areas of Malaysia. Trans R Soc Trop Med Hyg. 2000;94(3):280-4.

85. Audy J. The role of mite vectors in the natural history of scrub typhus. Proc 10th Int Congr Entomol. 1958;3:639-49.

86. Cadigan Jr FC, Andre RG, Bolton M, Gan E, Walker JS. The effect of habitat on the prevalence of human scrub typhus in Malaysia. Trans R Soc Trop Med Hyg. 1972;66(4):582-7.

87. Robinson DM, Gan E, Donaldson JR. The prevalence of scrub typhus antibodies in residents of West Malaysia. Trop Geogr Med. 1976;28(4):303-8.

88. Turner RW, Martoprawiro S, Padmowiryono SA. Dynamics of the plague transmission cycle in Central Java (Ecology of potential flea vectors). Bull Health Res Indones. 1974;2(2):15-37.

89. Hadi TR, Sarbini S, Dennis DT. Survey of small mammal ectoparasites in West Sumatra, Indonesia. Southeast Asian J Trop Med Public Health. 1981;12(2):275-7.

90. Elbel RE, Thaineua M. A flea and rodent control program for plague prevention in Thailand. Am J Trop Med Hyg. 1957;6:280-93.

91. Olson WP. Rat-flea indices, rainfall, and plague outbreaks in Vietnam, with emphasis on the Pleiku area. Am J Trop Med Hyg. 1969;18(4):621-8.

92. Brooks J, Naing UH, Walton D, Myint D, Tun U, Thaung U, et al. Plague in small mammals and humans in Rangoon, Burma. Southeast Asian J Trop Med Public Health. 1977;8(3):335-44

93. Tay ST, Mokhtar AS, Zain SNM, Low KC. Isolation and molecular identification of bartonellae from wild rats (Rattus Species) in Malaysia. Am J Trop Med Hyg. 2014:90(6):1039-42.

94. Smith CEG. A virus resembling Russian spring-summer encephalitis virus from an ixodid tick in Malaya. Nature (Lond). 1956;178:581-2.

95. Tan SK, Smith CEG, Mcmahon DA, Bowen ETW. Lanjan virus, a new agen isolated from Dermacentor auratus in Malaya. Nature. 1967;214:1154-5.

96. Hoogstraal H, Wassef HY. Dermacentor (Indocentor) auratus (Acari: Ixodoidea: Ixodidae): hosts, distribution, and medical importance in tropical Asia. J Med Entomol. 1985:22(2):170-7.

97. Sandosham AA, Nordin K. Animal parasites of animals which affect man in Malaysia. Med J Malaya. 1967:22(1):16-25.

98. Saleh I, Ho TM. Ectoparasites of some laboratory animals. Trop Biomed. 1989;6:113-6.

99. Boese $J$ L. Tissue reactions at the site of attachment of chiggers. J Med Entomol. 1972;9(6):591.

100. Audy J, Vercammen-Grandjean P. Endoparasitism in trombiculid mites. Nature. 1955;175:263-4.

101. Nadchatram M, Domrow R. The intranasal species of Lauremtella. J Med Entomol. 1964;1(1):29-39.

102. Zhang RL, Zhang B. Prospect of using DNA barcoding for species identification and evaluation of the accuracy of sequence databases for ticks (Acari: Ixodida). Ticks Tick Borne Dis. 2014:5:352-8.

\section{Submit your next manuscript to BioMed Central and take full advantage of:}

- Convenient online submission

- Thorough peer review

- No space constraints or color figure charges

- Immediate publication on acceptance

- Inclusion in PubMed, CAS, Scopus and Google Scholar

- Research which is freely available for redistribution 